Chazalnoel, Vera Goldschmidt, Karoline Popp, Daria Mokhnacheva, Elizabeth Warn, Lorenzo Guadagno, Rabab Fatima, Sabira Coelho, Alex Flavell, режим електронного доступу: https://publications.iom.int/system/files/pdf/meclep_ glossary_en.pdf?language $=$ en

3. Міграційні процеси в сучасному світі: світовий, регіональний та національний виміри (понятійний апарат, концептуальні підходи, теорія та практика). Енциклопедія / Упоряд. Ю.І. Римаренко; За редакцією Юрія Римаренка., Київ, Видавництво «Довіра», 1998 р. 912 с.

DOI https://doi.org/10.30525/978-9934-26-074-2-28

\title{
ПОШУК ОПТИМАЛЬНОЇ ФОРМИ ДЕЦЕНТРАЛІЗАЦІЇ ПУБЛІЧНОЇ ВЛАДИ В УКРАЇНІ
}

\author{
Антонюк О. М. \\ аспірантка кафедри господарського та адміністративного права \\ факультету соиіології і права \\ Національного технічного університету Украйни \\ «Київський політехнічний інститут імені Ігоря Сікорського» \\ м. Київ, Украӥна
}

Однією 3 умов ефективного здійснення реформування органів виконавчої влади на різних рівнях $є$ визначення оптимальної моделі децентралізації влади, яка враховує особливості адміністративнотериторіального устрою держави, розмір території, соціально-економічне становище регіонів, бюджетний потенціал територій тощо. Для визначення такої моделі, передусім, слід з'ясувати можливі форми децентралізації влади.

У науковій літературі зазначається, що децентралізація може набувати таких форм: 1) деволюція - передача центральним урядом повноважень субнаціональним одиницям при збереженні суверенітету центру; 2) делегування - передача повноважень та відповідальності на місцевий рівень при збереженні владної вертикалі; 3) деконцентрація розподіл адміністративних повноважень між органами державної влади різного рівня; 4) дивестиція - передача планування, адміністративної влади або інших функцій неприбутковим, приватним або громадським організаціям [1, с. 80].

Подібної думки дотримуються й інші науковці, пропонуючи при цьому більш розширене тлумачення кожної з наведених форм. Зокрема, А.О. Маслов та А.Т.Гладковська наводять такі визначення форм децентралізації влади: деконцентрація - передбачає перерозподіл влади і 
відповідальності до місцевих органів управління, до того ж таких, які не завжди є місцевими підрозділами центральних органів управління; за деволюції місцевим органам влади повністю передається відповідальність, влада, ресурси та джерела доходів, що робить місцеву владу автономною і незалежною; делегування - передача влади і відповідальності від уряду на інший рівень управління зі збереженням ієрархічної підпорядкованості місцевої влади центральному уряду і його міністерствам, що децентралізуються; дивестиція - планування та адміністративна влада або інші функції передаються в добровільні, приватні або громадські організації; часто здійснюється 3 частковою передачею адміністративних функцій у поєднанні 3 дерегуляцією або частковою приватизацією [2, с. 5].

Інші науковці виокремлюють лише дві форми реформування публічної влади через передачу повноважень згори до низу - деконцентрація та децентралізація, зазначаючи, що деконцентрація може переходити у децентралізацію або здійснюватися поряд із децентралізацією на своєму власному полі влади; також можливий варіант, коли деконцентрація і децентралізація одночасно функціонують із різними за об’ємом повноваженнями з кожної сторони [3, с. 135].

Подібної думки дотримується Л.І. Кізюн, вважаючи, що існує децентралізація та інші форми передачі повноважень згори до низу. Зокрема, вчений зазначає, що оптимальною формою $\epsilon$ структурна диференціація єдиного процесу децентралізації, внаслідок якої з'являються адміністративна децентралізація (тобто «децентралізація-деконцентрація») та демократична децентралізація (або просто «децентралізація»). У разі сприйняття зазначеного підходу, на думку науковця, розмивається розрив між поняттями децентралізації та деконцентрації 3 їх наступним ототожненням і об'єднанням під загальною назвою децентралізації [4, с. 31].

Проте 3 такою точкою зору можна погодитись лише частково, оскільки, не заперечуючи в цілому можливості поєднання та взаємного переходу різних форм децентралізації, було б помилковим заперечувати існування окремих форм децентралізації, які вироблені сучасною правовою науково, - деволюції, дивестиції, делегування та деконцентрації, кожна з яких має свої особливості та якісні відмінності.

Таким чином, визначаючи оптимальну форму децентралізації влади для України, необхідно виходити з того, що деволюція $є$ однією з «найжорсткіших» форм децентралізації влади, яка передбачає повну передачу владних повноважень, ресурсів, включаючи бюджетні надходження та право ними розпоряджатися від центральної влади до органів місцевого самоврядування. Водночас така форма децентралізації, незважаючи на свою привабливість, може нести певні загрози територіальній цілісності та єдності держави, а тому може застосовуватися лише у невеликих унітарних державах. При цьому делегування, як форма 
децентралізації, також не є оптимальною, зважаючи на те, що передача владних повноважень супроводжується контролем зі сторони центральних органів влади за виконанням таких повноважень .що не може свідчити про самостійність місцевої влади.

Щодо інших форм децентралізації влади - дивестиції та деконцентрації, то ці форми є більш прийнятними для України, однак у чистому вигляді кожна 3 них має, як певні недоліки, так і переваги. Наприклад, дивестиція може призвести до монополізації матеріальних ресурсів та зосередження їх у недержавних організаціях, які при розпорядженні такими ресурсами можуть не враховувати інтереси деяких верств населення. Тому доцільно поєднувати окремі форми децентралізації, враховуючи деякі нагальні проблеми, потреби та особливості організації публічної влади, що існують у державі.

Стосовно України, то 3 цього приводу слушною видається думка науковців, які вважають, що система державного управління в Україні повинна формуватися на основі балансу, тобто поєднання принципів децентралізації та централізації публічної влади, як складових елементів одного явища. Це означає з одного боку автономію місцевого самоврядування 3 передачею йому управлінських повноважень щодо вирішення питань місцевої громади задля підвищення рівня життя іiі членів та активного залучення до процесу прийняття рішень i контролю за їх виконанням [5, с. 152$]$.

Таким чином, оптимальна модель реформи децентралізації влади в Україні, передусім, повинна вирішувати такі завдання: 1) формування оптимальної організації адміністративно-територіального устрою в Україні, за якого забезпечується збереження унітарності, єдності та цілісності держави 3 одночасним розширенням повноважень місцевого самоврядування; 2) чітке розмежування питань місцевого, регіонального та загальнодержавного значення, відповідно до яких має здійснюватися розподіл функцій, прав та відповідальності (повноважень) між органами публічної влади різного рівня; 3) збереження взаємодії та співробітництва між різними рівнями органів виконавчої влади шляхом залучення органів місцевого самоврядування до формування державної політики у різних сферах; 4) забезпечення спроможності органів влади різного рівня виконувати покладені на них повноваження, тобто формування певних принципів розподілу ресурсів, включаючи бюджетні надходження, між органами влади різного рівня, надання права розпоряджатися цими ресурсами на власний розсуд.

Виходячи 3 наведеного, видається, що найбільш прийнятною для України $є$ змішана форма децентралізації, яка передбачає поєднання деконцентрації, деволюції, делегування та дивестиції, за якої до відання органів місцевого самоврядування будуть передані всі повноваження щодо вирішення питань місцевого значення із одночасним залученням останніх до участі у формуванні державної 
політики, створенням умов для виконання органами місцевого самоврядування своїх повноважень шляхом розподілу бюджетних ресурсів між органами влади різного рівня.

\title{
Література:
}

1. Мельничук Л.М. Принцип децентралізації влади як ключовий вектор модернізаційних перетворень у системі державного управління соціальним розвитком регіонів. Регіональне та муніципальне управління. 2015. № 7-8 (21-22). С. 77-84.

2. Маслов А.О., Гладковська А.Т. Сутність, типи, форми, можливості і загрози децентралізації. Ефективна економіка. 2019. № 2. URL: http://www.economy.nayka.com.ua/pdf/2_2019/13.pdf.

3. Дорош У. До визначення поняття децентралізації влади. Ефективність державного управління. 2017. Вип. 3 (52). Ч. 1. С. 130-137.

4. Кізюн Л.І. Децентралізація влади та суміжні поняття. Право. Людина. Довкілля. 2019. Vol. 10(1). С. 28-34.

5. Горобець Н.О., Троян О.А., Страшок Є.В. Поняття децентралізації публічної влади в Україні. Юридичний науковий електронний журнал. 2019. № 5. C. 149-152.

DOI https://doi.org/10.30525/978-9934-26-074-2-29

\section{ПУБЛІЧНІСТЬ ФІНАНСОВО-ІНВЕСТИЦІЙНИХ ПРАВОВІДНОСИН ЯК ЧАСТИНИ ФІНАНСОВИХ ПРАВОВІДНОСИН}

\author{
Бліхар М. М. \\ доктор юридичних наук, дочент, \\ професор кафедри адміністративного та інформачійного права \\ Навчально-наукового інституту права, \\ психології та інноваційної освіти \\ Національного університету «Львівська політехніка» \\ м. Львів, Україна
}

Публічність фінансово-інвестиційних правовідносин як частини фінансових правовідносин зумовлена такими важливими чинниками: поперше, правове регулювання інвестиційних фінансів охоплює широкі сфери суспільного життя країни і $є$ частиною загального фінансовоправового регулювання грошових потоків (інвестиції входять до фінансової системи держави); по-друге, інвестиційна діяльність - це складова частина цілісного механізму управління фінансами відповідно до 114 